\title{
THE DEPLETION ALLOWANCE RELATIVE TO AN OIL AND GAS RESOURCE UNDER CANADIAN INCOME TAX LAW
}

\author{
N. J. STEWART*
}

\author{
APPENDIX \\ CANADA TAX CASES /1960/ - Stikeman (Pages 280-281) \\ For 1949 and 1950
}

1201. (1) Where the taxpayer operates an oil or gas well or where the taxpayer is a person described as the trustee in subsection (1) of section 73 of the Act, the deduction allowed for a taxation year is $331 / 3$ per cent of the profits of the taxpayer for the year reasonably attributable to the production of oll or gas from the well.

(2) Where a person, other than the operator of an oil or gas well and the person described as the trustee in section 73 of the Act, has an interest in the proceeds from the sale of the products of the well or an interest in income from the operation of the well, the deduction allowed for a taxation year is 25 per cent of the amount in respect of such interest included in computing his income for the year.

(3) Where an amount received in respect of an interest in the income from the operation of a well is a dividend or is deemed by section 73 of the Act to be a dividend, no deduction shall be allowed under subsection (2) of this section.

(4) In computing the profits reasonably attributable to the production of oil or gas for the purpose of this section a deduction shall be made equal to the amounts, if any, deducted from income under the provisions of section 53 of chapter 25 of the Statutes of 1949 , Second Session, in respect of the well.

For 1951

1201. (1) Where the taxpayer operates an oil or gas well the deduction for a taxation year is $331 / 3$ per cent of the profits of the taxpaycr for the year reasonably attributable to the production of oil or gas from the well.

(2) Where a person, other than the operator has an interest in the proceeds from the sale of the products of an oil or gas well or an interest in income from the operation of the well, the deduction allowed for a taxation year is 25 per cent of the amount in respect of such interest included in compuling his income for the year.

(3) Where an amount received in respect of an interest in the income from the operation of a well is a dividend or is deemed by the Act to be a dividend, no deduction shall be allowed under this section.

(4) Where the taxpayer operates more than one oil or gas well, the profits referred to in subsection one shall be the aggregate of the profits minus the aggregate of the losses of the taxpayer for the year reasonably attributable to the production of oil or gas from all wells operated by the taxpayer.

(5) In computing the profits reasonably attributable to the production of oil or gas for the purpose of this section a deduction shall be mnde equal to the amounts, if any, deducted in computing the taxpayer's income for the taxation year under the provistons of section 53 of Chapter 25 of the Statutes of 1949, Second Session.

\section{The Depletion allowance Relative to an Orl and Gas Resource Under Canadian Income Tax Law}

The allowance for depletion in Canada, although never so-called in the Income Tax Regulations, is authorized under s. 11(1) (b) of the Income \footnotetext{
- N. J. Stewart, Dlvision Administratlve Manager, Pan Amerjean Petroloum Corporation,
} 
Tax Act. ${ }^{1}$ Parliament, in its wisdom, has seen fit to enact legislation designed to recognize that when one sells products from a mine, a timber limit, or an oil or gas well, the proceeds of the sale are a mixture of both capital and income. As each ton of ore, each thousand board feet of lumber, each barrel of oil or each thousand cubic feet of gas is removed and sold, income is undoubtedly generated, but along with this income, the supply from which each of these commodities has been withdrawn has been moved one unit closer to exhaustion. Thus capital is also being consumed and the real profit made by the entrepreneur producing and selling each of these commodities cannot be measured without recognizing that he is gradually but inevitably producing himself out of business. Therefore the depletion allowance was introduced to create a deduction which is not measured by the costs of finding or producing the depleting commodity, but is rather a deduction measured as a percentage of yield.

Section 11 (1) (b) of the Income Tax Act simply states that notwithstanding the provisions of certain paragraphs of $\mathrm{s}$. 12 which would seem to rule to the contrary, the taxpayer may deduct, in computing his income for a taxation year;

(b) such amount as an allowance in respect of an oil or gas well, mine or timber

limit, if any, as is allowed to the taxpayer by regulation;

The regulations applicable to depletion in the petroleum industry are presently contained in Part XII of the Income Tax Regulations.

The subject of depletion has become intensely controversial, particularly in the United States, and to only a slightly lesser degree in Canada. It is much maligned, much misunderstood, and of much importance to the past, present and future of those involved with it, either as taxpayers or as tax gatherers. It is not as simple as it appears to be in the legislation granting the allowance, but the writer hopes to be able to explain its workings and its ramifications as simply as his own limitations and the limitations of the legislation will permit.

\section{History of the Depletion Allowance in Canada}

No paper on the depletion allowance in Canada could possibly do justice to the subject without tracing the history of its development to some degree. The writer shall not risk the immediate loss of his reader's interest altogether by chronicling the step-by-step and word-by-word changes that have been made in the depletion allowance in Canada since its inception. It is believed however that an awareness of the background of our depletion allowance is a prerequisite to a proper appreciation of what was apparently intended by Parliament in granting a depletion allowance, and the efficacy of the language used to grant this allowance in accomplishing the ends which Parliament has set out for it.

In 1917 the Income War Tax Act" required the Minister of National Revenue to make an allowance for the exhaustion of mines, timber limits and oil and gas wells in computing income. Current law makes no mention of the word "exhaustion", but the depletion allowance was born in an incubus constructed as a result of the recognition by Parliament of the fact that mines, timber limits and oil and gas wells do exhaust themselves. The original rate in the petroleum industry was $25 \%$ of the 
value of production to the operator and $25 \%$ to the royalty owner. In 1941, the allowance granted to the operators of oil wells drilled west of Ontario was increased to $331 / 3 \%$ of net income to the taxpayer. The depletion allowance in that year for gas wells continued to be $25 \%$. In 1949 the $33 \% \%$ rate was extended to income from natural gas, and the geographic limitation to wells west of Ontario was removed for both oil and gas wells. The percentage rates have remained at this level ever since 1949. But this is only a fragment of the history of the development of the depletion allowance, and reveals nothing of what these various rates applied to, nor when they were applied. That is the best part of the story and is really worth waiting for.

The depletion allowance granted throughout the period from 1917 to 1947 appeared in very general form in $\mathbf{s} 5$ (1) (a) of the Income War Tax Act as follows:

5. (1) Income as hereinafter defined shall for the purpose of this Act be subject to the following exemptions and deductions:-

(a) The Minister in determining the income derived from mining and from oil and gas wells and timber limits may make such an allowance for the exhaustion of the mines, wells and timber limits as he may deem just and fair, and in the case of leases of mines, oil and gas wells and timber limits, the lessor and lessee shall each be entitled to deduct a part of the allowance for exhaustion as they agree and in case the lessor and lessee do not agree the Minister shall have full power to apportion the deduction between them and his determination shall be conclusive."

This language vested a discretion in the Minister to grant or withhold an allowance in respect of the exhaustion of the resources mentioned therein. We are all familiar with the oft-expressed distate on the part of the taxpayer for the granting of ministerial discretion by Parliament in a taxing statute, since it always raises the spectre of a capricious and arbitrary decision on the part of the incumbent Minister, even though the courts have insisted that he is obliged to act reasonably in the circumstances. However this ministerial discretion appeared to serve the Department of National Revenue and the petroleum industry to an adequate degree for many years.

Prior to 1939, the allowance granted by the Minister was a hybrid thing, in that it amounted to a blanket allowance for both depletion and development costs. Negotiations by the Minister with oil and gas producers had resulted in a maximum allowance of $25 \%$ of gross revenue being granted where the Minister considered it appropriate. This aggregate allowance was apportioned in such a way that $25 \%$ of the net profits, after deduction of development costs from gross profits, was regarded as an allowance for depletion and the balance was said to be an allowance for development costs. This allocation was approved by the Exchequer Court in 1939, in the case of National Petroleum Corporation v. Minister of $\mathrm{Na}$ tional Revenue,' which turned on a 1939 assessment. Maclean J. described the depletion allowance in this case as follows:

It is a measure of the annual exhaustion of the mass and source of the oil ... in other words in the case of an oil-producing property, a deduction for 'depletion' is an allowance for another division of wasting capital assets before estimating net annual revenue. 
The allowance was considered by the court here as clearly aimed at permitting a recovery of capital as oil and gas resources were exhausted.

Then in 1939, the theory behind the granting of a depletion allowance appears to have undergone a change. Since the granting of any depletion allowance at all was purely discretionary in the Minister, that discretion was thereafter exercised in favor of permitting depletion only as an aid to the taxpayer in the recovery of his costs. In D. R. Fraser \& Co. v. Minister of National Revenue, a case involving assessments for the taxation years 1940 and 1941, the Minister had refused to allow any depletion to a licensee of Crown timber lands because the licensee had already recovered all of the costs of certain timber licenses through annual deductions which it had been permitted to claim. The Canadian courts had accepted the Minister's contention to this effect, stating that the only capital asset of the licensee which was in the process of wasting as cutting proceeded, was the sum paid for the license. The Privy Council, to which this case was appealed, noted that the appellant company was not the owner of the land nor of the timber thereon which was in the process of being exhausted, but was a mere licensee thereof. The appellant contended that it was wrong in principle to have regard to the capital cost of obtaining the right to cut and carry away the timber and that under the statute the Minister's duty was to consider what was a just and reasonable allowance for the exhaustion of the timber from its timber limits without relation to what the company had paid for the right to cut and acquire this right. Lord Macmillan, speaking for the Privy Council, held as follows:

It was thus made abundantly clear in the course of the proceedings that the Minister in exercising his discretion proceeded on the view that what was being exhausted was the timber belonging to the Crown which the appellant company were licensed to cut and acquire and that the only allowance for depletion which ought properly to be made in favor of the appellant company was in respect of the sum which they had paid for the privilege of cutting and acquiring the timber; this was the only capital asset of the appellant company which was in process of wasting as the cutting proceeded; and for such depletion the appellant company had already received allowances in past years to the extent of $100{ }^{\prime},{ }^{\prime \prime}$

This judgment clearly indicated that the Privy Council was disposed favorably toward the theory espoused by the Minister and by Canadian courts for the years immediately following 1939, that depletion was solely a cost recovery mechanism with no recognition being given to the exhaustion of the wasting asset, notwithstanding the provisions of $s$. 5 (1) (a) of the Income War Tax Act aforementioned.

Then in 1946 the Minister's discretionary power to fix the rate of depletion was revoked by an amendment to the Income War Tax Act, which provided that for 1947 and subsequent taxation years the rate of depletion would be fixed by regulation, but regulations promulgated pursuant to this amendment did not change the rate of $331 / 3 \%$ of net profit for oil wells and 25\% of net profit for gas wells. Then in 1948 the Income Tax Act was again amended ${ }^{*}$ to make specific provision for a depletion allowance for 1949 and subsequent taxation years, by introducing $s .11$ (1) (b), the wording of which has been retained to the present day. The actual allowances which could be claimed were described in Part XII of the Income Tax Regulations first established under the 1948 Income Tax

s (P.C.) [1848] 4 D.L.R. 776.

id. at p.783.

7 g.c. $1946, c, 55,8,4$

8 R.S.c. 1948, c. 52, 8. 11 (1) (b). 
Act by Order-in-Council P.C. 6471 and made applicable to the 1949 to 1952 taxation years. Only subsections (1) and (4) of section 1201 of these Regulations are relevant to this discussion. They read as follows:

1201. (1) Where the taxpayer operates an oil or gas well ... . the deduction allowed for a taxation year is $331 / 3$ per cent of the profits of the taxpayer for the ycar reasonably attributable to the production of oil or gas from the well.

(4) In computing the profits reasonably attributable to the production of oil or gas for the purpose of this stction a deduction shall be made equal to the amounts, if any, deducted from income under the provisions of section 53 of Chapter 25 of the Statutes of 1949, Second Session, in respect of the well.

This language raised the immediate question of whether an operator was obliged to compute his depletion allowance in Canada on a well-bywell basis or on an overall basis. Ordinarily, the computation of depletion on a well-by-well basis will be enormously different from the computation on an overall basis for any given operator. This issue was brought before the Income Tax Appeal Board in the case of Home Oil Company Limited v. Minister of National Revenue." The appellant contended that the words "profit ... . from an oil or gas well" in the regulations applicable to 1948 and 1949 allowed the taxpayer to ascertain the profits from each well separately, and therefore to determine his depletion on a well-by-well basis. The Income Tax Appeal Board dismissed the appeal by the taxpayer from income tax assessment for the years 1949 and 1950.

The case was then appealed to the Exchequer Court before Thorson P. who upheld the dismissal of the taxpayer's claim. ${ }^{20}$ He felt that the use of the word "well" in the singular in section 1201 of the Regulations does not settle the matter in favor of well-by-well depletion because section 31 (j) of the Interpretation Act" provides that unless the contrary intention appears, words in the singular include the plural. The Court further held that the word "well" should read as including "wells" because there could be no justification for assuming that it was applicable only to wells operated at a profit. The amount of the allowance to which the taxpayer was entitled must be considered in the light of the section read as a whole. "When it is so read it becomes clear that the appellant cannot bring its claims within the ambit of section 1201, for subsection (4) defines what deduction of expenditures must be made in computing the profits referred to in subsection (1) and the appellant has not made the required deduction. Subsection (4) specified that in computing the profits referred to in subsection (1) the deduction that was to be made should be equal to the amount of the expenditures deducted from income under section 53 of the Income Tax Amendment Act ,1949."

When this case was appealed to the Supreme Court of Canada,"2 Rand J., giving the unanimous judgment of the Court, reversed the decision of the Exchequer Court in favor of the Minister, holding as follows:

The use of the word 'profits' and of the expression 'from the well' is, in the general context of the Act, singular, and to me they bear a signification that differentiates them from both 'income' and 'well' or 'oil' . . . certainly the partitioned allowances to the lessor and lessee under section 11 (3) must be related to the profits strictly of at least the wells of the lessor: .... I am not in

o (1954) $10 \operatorname{Tax}$ A.B.C. 61.

10 [1954) C.T.C. Sol.

11 R.S. 1927, C. 1 .

12 [1955] C.T.C. 192. 
doubt, therefore, that the 'profits' of a 'well' are not intended to be identical in the sense claimed (by the respondent) with the income of a company from its total oil operations remaining after the deduction of the allowance under Section 53.13

The dispute also revolved around the question of whether or not the taxpayer was obliged to deduct the costs incurred in drilling non-productive wells before the depletion allowance was computed. In this respect Rand J. said:

Subsection (4) of the Regulations speaks of a deduction equal to that made from income under section 53 'in rescept of the well' from the profits 'reasonably attributable to the production of oil or gas for the purpose of this section'. I take this to imply that the outlays charged against the income under section 53 must be 'reasonably attributable' to the wells that have produced a profit and that means especially or directly related to them.' I

As a result of this pronouncement, it was certain that for the taxation years 1949 and 1950, depletion could be computed on a well-by-well basis. However, this was of extremely small benefit to the industry because only a very few petroleum companies were in a taxable position during those years.

The decision in the Home Oil Case also turned to a substantial degree on the provisions of subsection (3) of section 11 of the Income Tax Act of $1949,{ }^{1 i}$ which stated that the lessor and the lessee could agree as to what portion of the depletion allowance each could deduct, but failing agreement the Minister could fix the portions. The Supreme Court held that the allowance for depletion to each of the lessor and lessee under subsection (3) of section 11 must be related to the profits strictly, in contradistinction to the profits and losses, of at least the wells of the same lessor, or it would be impossible to allocate the depletion allowance equitably between lessor and lessee. As a result of the final decision in the Home Oil Case, some taxpayers claimed that the Governor-in-Council did not have the authority under section 11 (1) (b) of the Income Tax Act 1940 to grant allowances other than on an individual well basis, and that the purported amendment to the regulation in 1951 to change the basis of the allowance to an aggregate basis had no legal force. It was suggested that, notwithstanding the rearguard action fought by the Minister through amendments to the Regulations in 1951, 1953 and 1956 which uniformly mentioned the "aggregate" of production for depletion purposes, all of these amendments still permitted the taxpayer to compute his depletion upon the production from each of his wells considered individually. These individual totals would then be aggregated in accordance with the requirements of the Regulations. It was argued that this procedure would be entirely consistent with the ruling of the Supreme Court of Canada in the Home Oil Case. The amendments which were applicable to the petroleum industry were those to subsection (1), paragraph (d) of subsection (4), and subsection (5) of section 1201 of the Income Tax Regulations, which then read as follows:

1201. (1) Where the taxpayer operates

(a) an oil or gas well,

(b) a precious metal mine,

(c) a base metal mine,

(d) an industrial mineral mine in respect of which the Minister of

13 Id. at 196.

1+ Ibld.

is Income Tax Amendment Act. S.C. 1949, Sccond Sesslon. c. 25. 
Mines and Technical Surveys has certified that the mineral is contained in a non-bedded deposit or that the mineral is sylvite, or (e) more than one of such wells or mines,

the deduction allowed is $331 / 3$ per cent of the aggregate of the profits minus the aggregate of the losses of the taxpayer, for the taxation year, reasonably attributable to the production of oil, gas, prime metal and industrial mineral from such wells and mines.

(4) For the purpose of this section,

(d) where someone other than the taxpayer has an interest in the proceeds from the sale of the products of a well or mine operated by the taxpayer, the value of the output for a taxation year from a well or mine is only that portion of the total value of the output from the well or mine than can reasonably be regarded as the proportionate share thereof that was included in computing the taxpayer's income.

(5) For the purpose of this Part, a taxpayer who has an interest in the proceeds of production from an oil or gas well or a mine under an agreement which provides that he shall share in the profits remaining after deducting the costs of operating the well or mine, shall be deemed to be a person who operates the woll or mine. it

The Minister also exerted efforts in the Act itself to obviate any further iconoclasm respecting the adequacy of the law to prevent well-bywell depletion, by amending section 11 of the Income Tax Act in 1956 in such a manner as to remove any doubts as to the power of the Governorin-Council to pass regulations under the authority of section $11(1)(b)$ which would require the computation of depletion on an overall basis. The new subsections, (2a) and (3) which were added to section 11, read as follows:

(2a) For greater certainty it is hercby declared that, in the case of a regulntion made under paragraph (b) of subsection (1) allowing to a taxpayer an amount in respect of an oil or gas well or a mine,

(a) there may be allowed to the taxpayer by such regulation an amount in respect of any or all oil or gas wells or mines in which the taxpayer has any interest, and

(b) notwithstanding any other provision contained in this Act, the Governor-in-Councll may prescribe the formula by which the amount that may be allowed to the taxpayer by such regulations shall be determined.

(3) For greater certainty it is hereby declared that a regulation made under paragraph (b) of subsection (1) of section 11 of the said Act before the coming into force of this Act may, insofar as such regulation has application to the 1956 or any subsequent taxation year, be revoked by the Governor-in-Council and the Governor-in-Council may, having regard to subscction (2a) of section 11 of the said Act as enacted by subsection (6) of this section, make or substitute therefor a new regulation with application to any or all of those taxation years. ${ }^{17}$

The provisions of section 1201 of the Regulations as they read during the taxation years 1951 to 1955 inclusive went before the Exchequer Court of Canada in 1959, in the case of Imperial Oil Limited v. Minister of $\mathrm{Na}$ tional Revenue." The chief amendment to section 1201 in 1951 consisted of the addition of a new subsection (4) which did not apply in the Home Oil Case since the latter turned on taxation years prior to 1951. New subsection (4) read as follows:

Where the taxpayer operates more than one oil or gas well, the profits referred to in subsection (1) shall be the aggregate of the profits minus the aggregate of the losses of the taxpayer for the year reasonably attributable to the production of oil and gas from all wells operated by the taxpayer.10

16 P.C. $1954-1294$.

17 S.C. 1956, c. 39.

18 [1959] C.T.C. 20.

10 P.C. 1951-4.4. 
A further important amendment ${ }^{20}$ in 1951 was the deletion of the words "in respect of the well" from the end of new subsection (5), formerly subsection (4) of the Regulations.

Thorson P. felt himself bound by the decision of the Supreme Court of Canada in the Home Oil Case and found that although certain changes had been made to section 1201 of the Regulations since the taxation years affected by the Home Oil Case, such changes still permitted the computation of depletion upon a well-by-well basis. He stated in his judgment as follows:

I have no hesitation in finding that in determining the base for the computation of the appellant's deductible allowance under the present section 1201 of the Regulations it is just as important that each producing well should be dealt with individually as it was under the section in its former state.

The importance of the words 'reasonably attributable' in subsections (1), (4) and (5) of section 1201 cannot be too strongly stressed. It is concerned only with producing wells."1

He then continued as follows:

Moreover the use of the words 'amounts, if any,' in subsection (5) further points to the need of an individual well basis for the computation of the allowance and negatives the contention of counsel for the respondent that subsection (5) requires the deduction of the total of the amounts that were deducted under section 53 for income tax purposes, regardless of whether they are attributable to the production of oil or gas from a well or not.22

The appellant's contentions in the case can be summarized as follows:

(1) that, notwithstanding subsection (4) or section 1201 of the Regulations, it was entitled to compute its depletion allowance on the basis of its profits from profitable producing wells only, without deduction of the losses of its loss-producing wells, because subsection (4) was ultra vires.

(2) that there should be no deduction of Imperial's exploration and other costs incurred in 1951 from the profits for that year because such costs were not related to the production of oil or gas from any of its wells in 1951.

(3) that there should be no deduction from profits subject to depletion of any amount of inventory that had been delivered from the producing department to some other department of Imperial Oil Limited, because such inventory bears no relationship to the production from wells considered individually for depletion purposes.

The Exchequer Court held that the computation of the base for depletion must be made for each producing well individually, since it must be determined whether or not each well made a profit or sustained a loss. However the Court held that since the appellant operated more than one well, the computation was subject to the definition of the base as set out in new subsection (4) of section 1201, i.e., that the aggregate of the profits of the profitable producing wells determined individually must be reduced by the aggregate of the losses of the loss producing wells determined individually, to establish the profit subject to depletion. In so holding, the Court had refused Imperial's submission that subsection (4) of section 1201 was ultra vires. Thorson $P$. felt that subsection (4) was quite within the authority of section 11 (1) (b) of the Income Tax Act, defining as it

20 P.C. $1951-443$.

$=1$ Supra n. 18, p. 43.

i: id. at p. 45 . 
did what amounted to profits under subsection (1) of section 1201 of the Regulations when the operator operated more than one well.

Thorson P. then returned to the good graces of the appellant by holding that subsection (5) of section 1201 did not require the appellant to deduct the costs of exploratory wells from its profits subject to depletion because these costs were not reasonably attributable to the producion of oil or gas from any of the appellant's wells in 1951. He also held that an inventory transfer by Imperial away from the producing department which resulted in unrealized profits in the marketing, manufacturing and supply divisions of the company should be recognized by the Minister, since for depletion purposes the profits reasonably attributable to the production of oil or gas from wells should be considered, and not inventory that has passed out of the producing department to another department of the appellant since the beginning of the taxation year in question. Thorson $P$. emphasized that the depletion computation was not concerned with the appellant's entire operation in all departments for the years, but only that portion thereof which was concerned with producing oil and gas.

This case was then taken before the Supreme Court of Canada where a divided Court upheld the Minister's appeal.": Judson J., speaking for the majority, held that the drilling, exploration and other costs of Imperial which were not related to a producing well had to be aggregated with the costs properly attributable to producing wells in determining the profit against which the depletion allowance was permitted by virtue of the provisions of new subsection (4) of Section 1201 of the Regulations. He stated as follows:

The reasonabiy attributable profits mentioned in subsection (5) are not on a well-by-well basis, taking only profitable wells, but on the composite basis as required by subsection (4). Then all section 53 items must be deducted-not, as formerly, only those 'in respect of the well'...

It simply means that whatever amounts the taxpayer deducts for determining taxable income must be deducted under regulation 1201. The presence of these words, 'the amounts, if any' in subsection (5), far from reinforcing the company's submission on the construction of the new regulations seems to be entirely consistent with the Minister's submission and to support the assessment. A taxpayer who deducts these section 53 items in one place for the purposes of determining taxable income, must do so in another for the purposes of determining the allowance under section 1201.:1

The majority of the Supreme Court also held that the inventory adjustment which Imperial contended resulted in an unrealized profit in supply, manufacturing and marketing inventories of $\$ 8,642,196$, was not supportable. Judson J. held that since no company makes a profit until oil is sold, the whole of the company's operations must be considered and the producing department alone could not be treated as a separate entity. Thus the transfer of inventory did not result in an 'unrealized profit', as was contended by the respondent, and the Minister was allowed to deduct the costs associated with this inventory in determining the profits from producing oil and gas.

Martland $J$,, who was one of a minority of three in deciding for the respondent, agreed with the approach to the problem taken by Thorson P. when the case was before the Exchequer Court, and it is submitted that he captured the proper inference of the language of sub-

:: [1960] C.T.C. 275

2 ld. at p. 286 . 
section (4) of section 1202 of the Regulations. Martland J. stated as follows:

When this subsection refers to the 'aggregate' of profits and the 'aggregate' of losses reasonably attributable to the production of oil or gas from all wells operated by the laxpayer it must mean the aggregate of the profits and the aggregate of the losses attributable to the individual oil or gas wells from which the oil or gas was obtained. It is speaking of an aggregate of individunl items. Consequently the computation must still be on a well-by-well basis, but subsection (4) added a new feature to the regulation in that losses on a per-well basis in respect of wells operated at a loss had also to be deducted from the aggregate of the profits earned by the individual profitable wells.:

Martland J. further held that the removal of the words "in respect of the well" from the end of new subsection (5), in respect of which the majority of the Court had laid such emphasis, was done simply for the purpose of making it conform with the provisions introduced in the new subsection (4), a conclusion which appears entirely reasonable when the language of the two subsections is compared. With the greatest of respect, it is the writer's view that the decision of the majority of the Supreme Court of Canada in the Imperial Oil Case was inconsistent with its conclusions upon similar facts in the Home Oil Case; that its decision in the Imperial Oil Case does violence to the new language introduced in section 1201 of the Regulations for the taxation years under appeal; and that the minority views expressed by Martland J. and Ritchie J., and concurred in by Cartwright J., are definitely more compatible with the Regulation as it hen read. Whatever our feelings, the Imperial Oil Case determined the method of computing depletion for the taxation years 1951 and 1952 at least. It has been estimated that depletion allowable to oil companies for the years questioned by the Imperial Oil decision would exceed $\$ 60$ million and therefore it is small wonder that the outcome of this appeal was so anxiously awaited.

Further amendments to the provisions of section 1201 of the Regulations were enacted for the taxation years 1953 and 1955 inclusive to make it even more clear that depletion must be claimed on an overall basis and not on a well-by-well basis. For the taxation years 1956 and afterwards a further amendment to Section 1201 was enacted to set out the actual mechanics for the computation of the depletion allowance upon an overall basis, placing it beyond any doubt that depletion upon an individual well basis is no longer possible in Canada.

\section{The Determination of a Depletable Resource in Canada}

Whereas some confusion previously existed under the Regulations as to what was depletable, we were favored in 1963 with P.C. 1963-412 which brought forth a new paragraph (a) to section 1201 (1) of the Regulations which fairly adequately defines "resource" for depletion purposes.

This paragraph defines a "resource" to mean;

(i) an oil or gas well,

(ii) a bituminous sand deposit,

(iii) a base or precious metal mine, or

(iv) a mineral deposit in respect of which the Minister of Mines and Technical Surveys certifies that the principal mineral extracted is an industrial mineral contained in a non-bedded deposit, and the principal mineral is one of a number named in the section and is extracted in a specified manner.

Since this paper is concerned almost exclusively with depletion as it applies to oil and gas, any further remarks upon the determination of a 
depletable resource will be confined to those parts of the law dealing with oil and gas, although considerable and increasing interest is being shown by many petroleum and other companies in other minerals and the depletion that may be allowable in respect thereof. Exotic and interesting as these other depletion considerations may be, time will not permit digressing into them on this occasion.

Any person who has an interest in the proceeds of production of a "resource" as defined in paragraph (a) of section 1201 (1) is entitled to a depletion allowance. The exact allowance to which the owners of various interests in a "resource" can lay claim will be discussed in detail later.

\section{Persons Entitled to Depletion Allowances: The Rates and Limitations THEREON}

Paragraph (b) of section 1201 (1) of the Regulations provides that a person having an interest in the proceeds of production from a resource under an agreement providing that he shares in the profits remaining after deducting the costs of operating the resource, is deemed to be one who operates the resource. This provision has resolved most of the doubts as to who is entitled to the $331 / 3 \%$ net depletion allowance for operators, and who is entitled to the $25 \%$ gross depletion allowance for non-operators. The necessity of an agreement to cover the operation of the resource is highly questionable, since undoubtedly the owner of a fee simple interest in a resource could develop it himself in the absence of an agreement, and claim the operator's depletion allowance on his net profits. Before 1958, when the description of an "operating" interest was much less precise in the Regulations, the fears of some participants in joint ventures that they might not qualify for the $331 / 3 \%$ rate were evidenced by the employment in joint operating agreements of such imaginative nomenclature as "joint operator" for those not actually conducting operations, while the operator himself was termed the "manager operator". However the arrival in 1958 of the present paragraph (b) of section 1201 (1) has dissipated most of the doubts as to who is an "operator" for depletion purposes.

The owners of a working interest or of a rental or royalty interest have no problems in determining their depletion allowances in Canada. Also, the owner of a carried interest, who bears no out-of-pocket operating expenses, but must await the recovery of the operating costs by the working interest party or parties before he receives any profits, clearly qualifies as an "operator", since he too shares in the profits remaining after prior deduction of the costs of recovering the resources. The rather imprecise expression "costs of operating the resource" in paragraph (b) is considered by the Department of National Revenue to be sufficiently broad to include drilling and lifting costs, overhead costs, labor and materials, as well as ordinary operating expenses and should not be read restrictively as meaning only "operating expenses" as defined in most joint operating agreements.

The following briefly outlines the means of computing the various depletion allowances;

\section{(i) Operators}

Section 1201 (2) allows the "operator" of a well to deduct $331 / 3 \%$ of the aggregate of all profits reasonably attributable to the production of 
oil or gas, including bituminous sands, from all resources which he operates, less the aggregate of all deductions mentioned in section 1201 (4), which include:

(a) any losses reasonably attributatble to the production of oil or gas from the resources which he operates,

(b) all deductions for the year for exploration or development pursuant to section $83 \mathrm{~A}$ or 851 of the Income Tax Act, which deductions must be claimed each year to the extent of taxable income; and all deductions that the taxpayer might have been entitled to under old section 53 of the 1949 Income Tax Act, or under any previous legislation, or under section 1204 of the Regulations.

(c) All capital cost allowances deducted in the year for property acquired for the purpose of exploring for or developing oil or gas, to the extent such capital cost allowance was not previously deducted in computing the profits from production.

(d) All interest deductions taken in the year respecting borrowed money used for the purpose of acquiring property for exploring for or developing oil or gas production, or borrowed for the purpose of paying for the search for oil and gas resources, to the extent such interest deductions have not already been claimed.

The "profits" from a taxpayer's oil or gas wells, for the purpose of his depletion computation, are therefore quite different from his taxable income. It is considered that no profit is "reasonably attributable to the production of oil or gas" until the product is actually sold or disposed of. No allowance for an unrealized profit can be included in the profit computation. ${ }^{20}$ However the value of oil or gas used by an operator in his production operations can be included in his profit computation for depletion purposes. ${ }^{27}$ As to whether this principle can be stretched to cover oil or gas used for fuel by an operator of a gas plant is extremely doubtful, having regard to the functions of the plant. In any event, most operators of production facilities will claim their depletion allowances upon the value of the oil or gas produced before it moves into the plant fuel stage, even if the same operator happens to operate the wells and the plant. In effect he makes a sale of the oil or gas to the plant account for fuel and this profit should be depletable.

It is obvious that an "operator" in Canada is entitled to a net depletion allowance only, and to the extent that his expenses equal or exceed income in any taxation year, his depletion allowance is lost. There is no possibility of deferring a claim for depletion allowance is lost. There is no the same sense as deductions allowed under section $83 \mathrm{~A}$ of the Income Tax Act can be deferred. If there is no profit, there is no depletion allowed. The business loss carry-forward from the immediately preceding five years and the carry-back from the taxation year immediately following the taxation year authorized under section 27 (1) (e) of the Income Tax Act can be utilized in profitable years to claim depletion for years in which it could not be claimed because of loss producing years, but otherwise it is irretrievably lost because there is no profit against which it can be set off. 


\section{(ii) Non-Operators}

Section 1202 (1) of the Regulations, which deals with the depletion allowable to non-operators, permits the owners of a rental or royalty computed by reference to production, to deduct $25 \%$ of the amount thereof. It also states that anyone other than an operator who has an interest in a resource and in the proceeds from the sale thereof, may deduct 25\% of the amount received pursuant to such interest. It is interesting to note here that until 1961 when paragraph (a) of section 1201 (1) was amended, a person other than an operator could claim a $25 \%$ depletion allowance on the proceeds received from the sale of the products of a resource without owning any interest in the resource itself. Thus a net profits interest, which ordinarily vests no right in the holder thereof to the oil and gas itself but only in the proceeds from the sale thereof, could claim $25 \%$ depletion on his gross receipts until 1961, but not after the amendment to this paragraph. Paradoxically, the owner of a net profits interest must now claim an "operator's" allowance under section 1201 (1) (b) because he does have an interest in ... "the proceeds remaining after deducting the costs of operating the resource," even though he has no control over operations whatever. It may be that debts owed pursuant to conventional financing indentures may be entitled to the operator's net depletion allowance, but this is a considerable stretch of the concept of "operator", even though the claimant to such debt may quite reasonably claim that he hopes to share in the profits remaining after deduction of the costs of operating, as provided for operators. However it is obvious from the current wording of the Regulations that the non-operator's $25 \%$ gross depletion allowance is not available to any persons to whom debts are owing under the various instruments used in financing oil or gas ventures, unless such persons receive a rental or royalty computed by reference to oil or gas production, or actually own an interest in the resource itself. That this is the definite intention of the Department of National Revenue is evidenced by the 1961 amendments to paragraph (a) of section 1202 (1) aforementioned. It is entirely possible that the courts may have to decide a "substance vs. form" case on this point at some time in the future, when some taxpayer contends that his agreement assures him of an interest in a resource which should be depletable, while the Department contends that the interest is in substance really only a debt which was made referable to oil and gas production in the agreement strictly for the purpose of affording an undeserved depletion allowance to the taxpayer. The line drawn by the legislation is a fine one, and it will be surprising if it is not submitted to litigation at some future time.

\section{(iii) Investors}

For those who invest funds in petroleum companies a depletion allowance is granted under Part XII of the Regulations. If a shareholder receives a dividend from a corporation, resident in Canada which produces "mineral profits," (which include the total of all profits described in sections 1201 and 1202 of the Regulations, plus dividends from still another corporation which generated at least $75 \%$ of its income from mineral profits), this shareholder may claim a depletion allowance in respect of the dividend. The allowance is $10 \%$ of the dividend, if 
paid by a company whose income is generated at least $25 \%$ but not over $50 \%$ from mineral profits. If the share of income attributable to mineral profits of the dividend-paying company is over $50 \%$ but less than $75 \%$, the shareholder depletes his dividend at $15 \%$; and if the share of income exceeds $75 \%$, the shareholder may claim a $20 \%$ depletion allowance.

Dividends paid by non-resident companies are no longer eligible for depletion deductions since an amendment to the Regulations in 1958 which repealed old section 1301 of the Regulations.

Section 1302, which states that for the purposes of Part XIII, a dividend does not include an amount deemed by the Act to be a dividend, effectively forecloses any right to claim depletion on a stock dividend. Only dividends in cash or kind qualify for the allowance.

Depletable dividends may also be received by a taxpayer through the medium of a trust or estate.

\section{(iv) Others}

Since estates or trusts are taxed as individuals in Canada pursuant to section 63 of the Income Tax Act, if they should operate a "resource" as defined in section 1201 (1) of the Regulations, or receive any royalty or rental therefrom, the income from such resource is depletable by them on the same basis as for individuals.

For those Canadian taxpayers who have interests in "resources" outside Canada, whether as operators or otherwise, no depletion is allowable in Canada upon any profits thereform.

As a concluding remark upon the mechanics of computing depletion in Canada, it is worth while mentioning a new problem that has arisen from the enactment in 1962 of new subsection (5b) of section 83A of the Income Tax Act. This subsection states that in the case of any oil company disposing of a petroleum right of the type described in new subsection (5a) of section 83A, an income tax shall be imposed upon any amount received by the transferor as consideration for such disposition. The language of subsection (5b) does not qualify such consideration as drilling or exploration expense. If receipt of this consideration is to be viewed in the same light as income from the sale of petroleum produced, it will be depletable, but if not, in determining taxable income it will not be depletable and will have to be segregated from other income from the sale of petroleum products. Furthermore, if such consideration is not deemed to be oil and gas income, it will result in the conversion of depletable income from the property in the hands of the transferor, to non-depletable income in the hands of the transferee after the sale or disposition.

\section{Depletion of Profits From Processing and Cyching Operations}

Many real and unanswered questions arise in the determination of the depletion allowance which shall be granted in respect of profits from processing gas for market and profits attributable to the cycling of gas to maintain reservoir pressure. In the United States, depletion upon the profits attributable to processing gas is dependent upon whether or not the profit arises from an operation eligible for depletion. One experienced 
author in the United States ${ }^{28}$ characterizes the operative phases of processing gas under four headings: separation, absorption, fractionation and injection. Profits reasonably attributable to an operation which is essentially a producing function are depletable in the United States, and these operations would include all separation of the gas from the reservoir and well, as well as the injection of the plant residue gas into the formation, whether for the maintenance of reservoir pressure, ordinary secondary recovery or for some other form of recovery such as a miscible flood. But any profits reasonably attributable to manufacturing operations are, quite predictably, not eligible for depletion. The fractionation of a gas into new products would almost invariably be considered a plant manufacturing process, and the absorption function in most cases will also fall into the manufacturing category.

Although the Taxation Division in Canada is aware of the treatment in the United States of profits attributable to processing for depletion purposes, its approach varies significantly from the American approach. This is not surprising, since our law on the subject is quite different from that in the United States. Section 1201(5) (d) of the Regulations under the Income Tax Act states as follows.

... profits reasonably attributable to the production of oil or gas from a well or bituminous sand deposit shall not include profits derived from transporting or processing the oil or gas.

The Taxation Division will allow depletion in respect of profits attributable to certain basic separation operations in the field, such as the removal of water from gas, on the theory that these are "producing" and not "processing" operations. However, profits attributable to any plant operation which is more sophisticated than a basic field operation are considered "processing" profits and therefore not eligible for depletion in Canada. It is interesting to note that some Canadian taxpayers have gone to great pains to eliminate the word "processing" from any plant agreement which they prepare, replacing such wording with suitable euphemisms which they hope will bolster their contention that until the gas is actually in a condition in which it can be sold, it is still in the "producing" phase and profits attributable thereto are subject to depletion. There may be an argument to this effect, and such venturesome taxpayers are wished well, but there seems to be little to sustain this argument under existing law, which deals only with "processing" and makes no reference to the marketability of the product after processing.

Any profits attributable to the movement of gas through a gathering system or other pipeline carriage cannot be reduced by a depletion allowance because these have been held by the Department to fall into the interdicted category of profits from "transporting" the gas.

With respect to cycling operations, the Taxation Division has stated that the injection of plant residue in a cycling program, regardless of the purpose to be served in the reservoir, is so closely related to the production of plant products that it can conceive of this operation only in terms of "processing". Furthermore the costs of injection of gas are not permitted to be set off against the value of sweetened and marketable gas in determining the profit from the sale of the latter. This may be an area in which some compromise of the stand taken by the Department of National

28 Raymond Myers, The Law of Pooling and Unitization, (1957) D. 286 and 2 . 
Revenue might be achieved by a taxpayer who can demonstrate by eloquent and forceful argument that cycling gas does not change the character of the gas being cycled through "processing", but merely returns the same basic gas to the formation from which it was withdrawn a short time previously. This theory would seem particularly defensible in the case of a cycling project conducted for pressure maintenance purposes.

The term, "profit attributable to" a separation project or to a gathering system requires further comment. One might ask how a profit is attributable to a necessary but purely preliminary operation which itself produces no profit. Undoubtedly this is where those venturesome taxpayers mentioned earlier will stand and fight for their right to deplete all profits made from the sale of gas which are allocable to "producing operations" as they define them. They will argue that no profit is produced until a product is sold, and that the profit attributable only to the last stage before sale is "processing" profit and therefore ineligible for depletion under section 1201 (5) (d) of the Regulations. The Taxation Division has taken the position that the profits from the sale of gas or from the sale of plant products are created through the carrying on by the operator of all the necessary steps after the gas is produced in the field, and that these profits must be allocated back from the sale price to each of these steps or "processes" upon some formula basis found reasonable after negotiation between the taxpayer and the Department. This seems to be an area in which litigation will probably ensue before the last word is said upon depletion of plant profits or upon depletion of profits allocable to cycling operations.

\section{Short Comparison With Depletion Under U.S. Internal Revenue Code}

Allowable depletion in the United States is generally known to be more favorable to the taxpayer than percentage depletion in Canada. In the United States, the taxpayer is obliged to take the greater of two depletion allowances, percentage depletion or cost depletion. Each must be separately computed to demonstrate that the larger of the two allowances is being claimed.

Percentage depletion is allowable at $271 / 2 \%$ of gross income from each property interest held by the taxpayer, up to a maximum of $50 \%$ of net income. In computing the gross income against which the $271 / 2 \%$ rate is applied, the taxpayer must exclude all royalties paid, as well as what is called "bonus exhaustion", which is computed by dividing the bonus paid for acquiring the lease by the estimated recoverable oil reserves and multiplying the result by the current year's production. In computing net income for the purpose of determining the $50 \%$ of net income limitation upon the $271 / 2 \%$ allowance, the taxpayer does not deduct bonus exhaustion from gross income, but he does deduct operating, development and overhead expenses, depreciation and taxes assessed against the property.29 Fifty per cent of the net income so determined is the maximum percentage depletion allowed.

Cost depletion is computed by dividing the cost of property, exclusive of the equipment thereon, by the estimated recoverable reserves of oil or gas measured in barrels or in thousands of cubic feet to obtain a unit

20 See Leland E. Flike, Federal Taration of OAl and Gas Transactions, (1958) p. 39 and 4. 
cost per barrel or per thousand cubic feet. The current year's cost depletion is then obtained by multiplying the cost depletion unit so determined by the number of barrels or thousand cubic feet of gas sold in that year.

Any person owning an economic interest in an oil and gas property is entitled to depletion in the United States. An economic interest may be a fee simple interest in minerals, an interest in an oil and gas lease, an overriding royalty, an oil payment or even a net profits interest. The amount for which the oil and gas is sold in the vicinity of the well during the taxation year is the basis for computing the depletion allowance. The economic interest must be in the oil and gas itself and not in a mere debt measured by oil and gas production, if depletion is to be allowed. The computation of allowable depletion in the United States can obviously become highly complicated if a company owns varying interests, from royalty to working interests, in a number of horizons which are producing through individual wells in a particular lease which has been unitized with other leases in a particular area. Each of these interests forms a separate property which must be considered separately as to its income and its expenses, for both percentage and cost depletion purposes.

When compared with Canada's depletion allowance however, the difficulties and complexities of the American system are worth mastering. The American taxpayer need consider only his successful ventures in determining his costs. He is not obliged to deduct the expenses of exploration operations, of unsuccessful drilling upon tracts other than the one being depleted, nor does the bonus paid for unsuccessful leases form a part of his computations. All of these expenses would reduce his income subject to depletion if he were operating in Canada.

The result is that the American taxpayer realizes depletion in much greater amounts (estimated at $18 \%$ more in a survey prepared by the Colorado School of Mines in 1955), than the Canadian taxpayer. Furthermore, since allowable depletion can be realized in the United States as soon as production is encountered by an operator on a property-by-property basis, he gets this deduction many years earlier than his Canadian counterpart who must aggregate all of his properties and recover the costs of all of his successful ventures as well as the losses of all of his unsuccessful ventures before he has a net over-all profit against which depletion is allowed in Canada.

\section{Is a Depletion Allowance Needed by the Canadian Petroleum INDUSTRY?}

Discussions anywhere in North America on the justification for a depletion allowance are like golf or strong drink-they bring out the best and the worst in a man. Seemingly, a great deal depends upon the direction from which the depletion allowance is viewed. The bulwarks of the defence of depletion as a means of sustaining and encouraging petroleum exploration are raised in large measure by those who live in areas in which petroleum products are produced. The attacks upon depletion are led, in the main, by those who live in areas which consume but do not produce petroleum, and where depletion is viewed as some kind of governmental handout that oil millionaires have successfully lobbied through their government into an insidious piece of legislation. 
But this dicotomy between supporters and critics does not always hold true, since strong censure of the depletion allowance sometimes emanates from the very heartland of petroleum producing areas. As recently as three months ago, Dr. W. R. Wright, a young professor of economics at the University of Alberta in Calgary, entered the limelight by terming the depletion allowance in Canada a mechanism which imparts a stimulus to exploration through assuring a basic tax rate substantially less than the rate for non-resource industries, at a time when the oil industry has excess capacity, which represents an inefficient allocation of capital. He suggested also that the granting of depletion to the extent desired by the petroleum industry would give the industry prosperity at the expense of higher prices to the consumer.

Others, on many levels of government and business have from time to time added their voices to the clamor that depletion walks hand in hand with the opulence of movie stars, Texas oil magnates and Alberta tycoons. Many believe that depletion can be deducted from profits of whatever kind, and that it goes on rewarding the rich at the expense of the poor long after the original investment of the rich man has been recovered. To many people, depletion has become a synonym for an undeserved benefit, a tax loophole which permits extraordinary benefits to petroleum investors. The fact that the mining and timber industries also enjoy a depletion deduction is largely overlooked in the popular scramble to heap vituperation upon the "oil barons" and the "gas pipeline buccaneers".

In attempting to assess the validity or invalidity of the depletion allowances in our Canadian tax structure in some objective manner, it is submitted that we must examine its basic objectives, the results of its existence in the statute books and the probable consequences if it should ever be repealed.

As mentioned earlier, governments in both Canada and the United States have sought to recognize, through the introduction of depletion allowances in each of their countries, that the extractive industries produce revenue which is both capital and income in nature because their production gradually exhausts the source of the product. That this recognition should not be a function of cost is manifest, since one man may spend $\$ 10,000$ and find a $\$ 1,000,000$ asset, while next door another man may spend $\$ 1,000,000$ and find only a $\$ 10,000$ asset, or nothing at all.

The only means by which an investor in an extractive industry can accurately determine how much capital he has is by measuring it as he depletes it. Depreciation allowances which are designed to make provision for the wearing out of replaceable plant or machinery assets, have proven themselves incapable of a proper recognition of the wasting away or exhaustion of the raw material itself. Finally, the depletion allowance was settled upon as a measure of the worth of the wasting asset in or on the ground. In the case of petroleum, it is a gauge of the worth of oil or gas in the ground, measured by a known amount of oil or gas produced at a known price when produced. By this means, governments have sought to allow those in the petroleum industry to recover their capital free of tax, which is or should be a basic objective of any equitable tax system. The costs of services, machinery and installations which form the remainder of the capital expended by the petroleum investor are.recovered 
by means of depreciation and other deductions, but the capital portion of the revenue produced by the oil operator through the exhaustion of his reservoir receives no recognition whatever except through the granting of the depletion allowance.

If the depletion allowance is the great bonanza to the petroleum investor that it has been painted to be, surely this would be reflected in unusual profits for those receiving it. What, therefore are the results of deductions for depletion?

In the United States, oil company earnings, notwithstanding the more favorable depletion allowances in that country, have consistently averaged less than manufacturing company earnings. From 1925 to 1962, United States oil companies averaged $9.7 \%$ return on net assets after tax, while manufacturing companies averaged $10.4 \%$ return. For 1962 the rate was $10.5 \%$ for oil companies and $10.9 \%$ for manufacturing companies. For 1963 the comparisons show $9.1 \%$ for oil companies and $10.3 \%$ for manufacturing companies.

In Canada, the average rate of return on new investment in the oil industry after tax during the period from 1948 to 1962 on a discounted cash flow basis varied considerably. ${ }^{30}$ From 1948 to 1952 the return was $18 \%$. From 1953 to 1957 , the return was $8 \%$, and from 1958 to 1962 the return was $2.5 \%$. This averages about $9.5 \%$ over the period since 1948, but the recent years show a marked decline to a quite unsatisfactory level. This decline is attributable chiefly to rising per barrel costs and to the low rate of discoveries in recent years. It is interesting to note a comparison of the cash return on total funds employed by thirty-nine major industries in Canada." The following are some of the industries compared and their comparative ranking:
1. Quarrying
2. Prospecting
5. Publishing and Printing
9. Construction
10. Transportation
14. Metal Fabricating
23. Wholesale Trade
26. Fishing
29. Pulp and Paper ....
30. Retail Trade
31. Oil and Natural Gas

$31.3 \%$
$24.9 \%$
$15.8 \%$
$14.4 \%$
$14.2 \%$
$13.3 \%$
$11.1 \%$
$10.9 \%$
$10.4 \%$
$10.2 \%$
$10.2 \%$

All extractive industries in Canada, exclusive of oil and gas, averaged a $15.8 \%$ return on the basis above-mentioned.

The conclusion is therefore forced upon us that the depletion allowance is not creating an undue beneft for the petroleum industry, since that industry is barely holding its own with other industries in the competition for the investment dollar, even with the benefit of depletion. In Canada in particular, where a considerable proportion of total production is produced by companies which have not yet and will not for some time in the future become eligible for depletion allowances, depletion cannot rationally be termed an undue benefit to those engaged in the search for and the production of oil and gas.

so Canadian Petroleum Assoclation Submission to the Royal Commission on Taxation. 1963 , p. II-38.

a2 Department of Nattonal Revenue, 1868 Taxation Statlaties. 
Let us look for a moment at the probable consequences of a repeal of the depletion allowance. From a purely practical standpoint, beyond any doubt much of the petroleum which has been discovered in Canada has been found by companies which do not now receive a depletion allowance but hope to find sufficient petroleum reserves in the future to enable them to realize upon this deduction. The Canadian Petroleum Association in its Submission to the Royal Commission on Taxation, stated that of the $\$ 6.7$ billions spent upon petroleum exploration and production in Canada to the end of 1962 , only $\$ 150$ millions of depletion has been claimed. ${ }^{32}$ This amounts to a $2.23 \%$ realization of depletion over the years, which is hardly a gigantic government handout as it has been described. The continuing exploration efforts by companies that have been able to claim depletion are predicated to a great extent on their being able to continue claiming this allowance. The suspension of depletion in Canada could not fail to have a catastrophic effect upon the economics of further exploratory activities of both those companies that have claimed depletion and those that hope to be able to in the future, since the investments upon which they depend to sustain their searches would inevitably be compromised, with a significant portion thereof being diverted to more lucrative fields of industrial endeavor. Canada, with only a 20-year supply of proven reserves of petroleum, would suffer a terrific blow through such a relocation of investment.

From the academic standpoint, it has been argued by Professor Arnold C. Harberger in a paper which he submitted, The Taxation of Mineral Industries, ${ }^{\text {s3 }}$ that percentage depletion in the United States leads to a distortion in allocating mineral resources, because depletion will attract undue investment in minerals, the production of which will increase to the point where, with an excess supply, the price of the minerals will fall. As a consequence of the concentration of investment in the mineral field, he predicts that there will be a shortage of investment in other industries, with a resultant increase in the costs of the products of these other industries.

Professor Stephen L. McDonald in his paper, Percentage Depletion and Tax Neutrality, ${ }^{34}$ challenges the arguments of Professor Harberger, particularly the latter's assumption that equal normal rates of return and equal normal capital turnover rates should and do prevail in all industries. Professor McDonald lays great stress on the fact that in the petroleum industry risks and costs are very high, while turnover of investment is very slow. As a consequence he commends the percentage depletion allowance as a means of achieving the tax neutrality or balance which should exist between the high risk petroleum industry and the lower risk and faster turnover of capital investment in the manufacturing industry.

However these arguments, both practical and academic, may appeal to you, the harsh realities of Canada's position in finding markets for the petroleum products which it produces have got to be faced realistically. It must be appreciated by all sophisticated Canadians that the billions of dollars which have been spent in the search for and in the recovery of petroleum products in this country were not spent merely to generate a

32 Id. at p. III-12.

93 Subcommittee on the Economic Report, 84th Contress, 1st Session, 1955, P. 439.

34 Nationnl Tax Journal, Vol, XTV (1981) p. 336. 
productive capacity equal to Canada's comparatively modest needs. The desire was and remains to find quantities of both oil and gas vastly in excess of the requirements of this nation, so that profits could be realized by governments and taxpayers alike from exports of these commodities. And yet when we examine Canada's prospects for exporting oil or gas, having regard for world supplies, world prices and geographic limitations, the only export market that is really open to us is in the United States, where competition for the consumer's dollar is already fierce and unwavering. To intrude into markets in the United States on an economic basis, within the limitations imposed by regulatory authorities in both Canada and the United States requires the production of oil and gas in Canada for the lowest possible cost. A very minor defference in basic and irreducible costs can mean the difference between penetrating a huge export market for Canadian petroleum products, and losing that market altogether. The loss of a tax deduction by Canadian producers can easily create this most important difference. Rather obviously then, depletion is a practical necessity in Canada from the standpoint of tax equality between the petroleum industry and other industries in Canada, as well as from the standpoint of meeting competition for the markets which the producer in Canada must obtain and retain if our petroleum industry is to prosper.

If a depletion allowance is necessary to the Canadian petroleum industry, the question then remains, is the current Canadian depletion allowance adequate? It is the writer's view that our present allowance is farcical, unfair and insufficient. Such charges demand substantiation and it is proposed to substantiate each of them.

A farce is defined as "a mere show, a sham," and this is precisely what an unsophisticated would-be investor is treated to when he regards the apparently large $331 \% \%$. depletion allowance offered to operators in Canada. He is tantalized into making his first investment, only to find that even if he finds production, as his production increases to the point where depletion is almost within his grasp, he is forced to spend more money on exploration or development operations, thereby constantly nudging the date of actual realization of depletion beyond his reach again. After several repetitions of this performance, he begins to feel like a man on a treadmill. He constantly presses forward but he gets no closer to his goal.

The unfairness of our depletion allowance is demonstrated by the fact that it tends to benefit the successful and already well-established companies, both Canadian and foreign, but eludes the grasp of the others who are not in a profitable position but who are in the greatest need of help. It provides very little direct incentive to explore, (although this is advanced as one of the prime reasons for its existence) because it militates in favor of the taxpayer who is quite content to play the production cards which he already has in his hand, while letting others take the risks and bear the great expenses of finding more production. No dynamic industry can afford to support this type of taxpayer.

Since money spent on exploration and development is deducted from income before depletion is calculated, all petroleum company taxpayers must therefore ask themselves the very difficult question-why spend money on the difficult game of exploration when you make more money 
if you don't? Fortunately, most taxpayers in the petroleum industry have assumed the responsibility of exploring for further reserves, in spite of this deterrent, because they realize they must find more reserves or succumb completely. A further consequence worthy of consideration is the fact that the combination of current deductions and the depletion allowance in Canada favors integrated over non-integrated companies, because the integrated company can set off its current exploration and production expenses against income from other parts of its organization, thus advancing the date upon which it can claim depletion far ahead of the depletion date for the non-integrated company which has no income other than that from the sale of production, against which to set off its deductions for exploration expenses.

The insufficiency of Canada's depletion allowance is often masked by the argument that the advantage of unlimited deferrability of unutilized deductions resulting from exploration and development expenses makes up for the less advantageous depletion allowance in Canada. Others argue that since the petroleum industry in Canada is permitted to deduct all its expenses, (save those incurred in acquiring machinery or equipment which are recovered through depreciation) these allowances in themselves place our petroleum industry in a position reasonably comparable with other Canadian companies. Still others contend that Canada does not have the enormous wealth of the United States and therefore can't afford the luxury of matching our depletion allowance with the more favorable allowance granted immediately south of our borders.

The proposition that the more liberal American depletion allowance is counterbalanced in its advantages by the unlimited deferrability of Canadian exploration and development expense deductions in excess of current income is demonstrably untrue in practice, as any number of comparative studies have shown. Deductions for drilling and development in the United States are substantially similar to our own, lacking only the characteristic of unlimited deferrability in matching Canadian allowances completely. Liberalized American depreciation allowances are superior to our own. Therefore once a company begins receiving income from the sale of production in either country, against which deductions for exploration and development expenses can be set off, the immediate realization of a much greater amount of depletion in the United States places the American company in a vastly superior position to that of the Canadian company which must customarily wait for years before recovering depletion at all, and then at a much smaller effective rate.

Ottawa has slumbered too soundly and too long in the pleasant dream that the tax load borne by the petroleum industry in Canada is reasonably comparable with the tax load of other Canadian industries, and therefore, as Browning wrote in Pippa Passes, "God's in his heavenAll's right with the world!" The facts are quite at odds with this illusion and Parliament cannot be disabused of this notion too soon. It is of little or no consequence that the petroleum industry bears a comparable tax load to that of other industries in Canada, even if this statement should be found to be accurate. The prices of petroleum products, the markets in which they can be sold both within and outside of Canada, and the types of petroleum products that can be sold are not determined in Canada or by Canadians, but by the forces of international competition. If, as said 
earlier, the only export market into which Canadian petroleum can intrude is in the United States, then we in Canada are forced to make our comparisons with the tax impact upon producers in that country and not in our own if we want to export.

The American producer is currently or prospectively enjoying even further advantages over his Canadian counterpart than the depletion advantages about which so much has been said. His corporate tax rates have already been reduced $2 \%$ and he can look forward with great anticipation to a further $2 \%$ reduction in 1965 . The American producer buys equipment at 100 cents on the dollar, but the Canadian producer, much of whose equipment is made in the United States, must use 108 cent dollars to buy the same equipment, (so long as the present currency differential in favor of the American dollar continues), in addition to pay ing various sales taxes and duties which further increase his costs of operating in comparison with his American counterpart.

If Canadian ambitions to compete economically for markets for our petroleum products are to be realized at all, it must be appreciated that some recognition must be given by Ottawa to the handicaps placed upon the Canadian producer by our tax legislation. The place to start is on the current depletion allowance, the shortcomings of which are so pronounced, so much in need of rectification, and yet so persistent.

\section{Suggested Amendments to the Regulations Applicable to the Depletion Allowance}

At the risk of repeating certain of the arguments which have already been advanced, the writer would like to draw upon some conclusions of Jacques Barbeau in The Rationale of the Canadian Treatment, ${ }^{35}$ because these conclusions point up the necessity for the type of amendment which it is suggested should be made to the Income Tax Regulations applicable to the depletion allowance in Canada. The charts which Mr. Barbeau includes in his article graphically illustrate the following facts to be true: ${ }^{30}$

(a) That as expenditures on exploration and development increase, the Canadian depletion allowance declines to the point where, when these expenditures match or exceed income, there is no depletion allowance available. Thus wells or even entire fields can be, and in fact in some cases are being physically depleted completely without any depletion allowance being realized by the operator thereof.

(b) That any company which spends more than $55 \%$ of its gross income upon exploration would be benefitted more by a $15 \%$ gross depletion allowance than by the present $33 \frac{1}{3} \%$ net depletion allowance.

(c) That any company spending more than $100 \%$ of its gross income upon exploration is presently losing depletion irretrievably; whereas under a gross depletion basis, companies spending in excess of $100 \%$ of gross income upon exploration would be credited with an increased carry-forward or a business loss which could be carried back one year or forward five years.

35 Oll and Gas Production and Taxes, 1963, by the Canadlan Tax Foundation, c. VIII, p. 256 and 11.

so Id. at p. 267 to 272 inclusive. 
(d) That if a $25 \%$ gross depletion allowance was granted, any company spending more than $25 \%$ of its gross income upon exploration would be better off than under the present $331 / 3 \%$ allowance, while those spending less than $25 \%$ of gross income upon exploration would be better off under the present allowance.

(e) That a limitation upon the depletion allowance which is a function of gross income would effectively compromise any incentive to spend in excess of gross income upon exploration and development in any taxation year in order to increase the depletion realization.

It is apparent that if section 1201 of the Regulations is amended to permit the computation of depletion on a gross basis, the depletion allowance will fulfill its objective of providing an incentive to explore. Furthermore, a gross depletion allowance would put integrated and non-integrated companies, as well as foreign and Canadian companies into a state approaching tax equilibrium.

The submissions of the Canadian Petroleum Association and the Independent Petroleum Association of Canada to the Royal Commission on Taxation in 1963 advocated a depletion allowance of $25 \%$ of gross income, without limitation. The justifications for the $25 \%$ rate are set out at length in these submissions and the writer does not propose to spend any time commenting upon them except to add his endorsement of the rate proposed as one which is reasonable and defensible in the circumstances.

It is submitted however that it is not reasonable to anticipate that the Canadian government will adopt a $25 \%$ rate of depletion on gross income without any limitation, for a number of reasons. First and foremost, such an allowance would result in a reduction in the tax payable by a number of large integrated oil companies which are taxable in Canada of such proportions that the fiscus probably would not tolerate it. Secondly, such a depletion allowance would be even more favorable to the industry in Canada than the much vaunted and accursed percentage depletion allowance in the United States, a comparison for which it is suggested Parliament has no enthusiasm. Thirdly, such a depletion allowance is not the incentive to explore that it should be, although if such an allowance should be granted by Parliament, its benefits would undoubtedly be reflected in greater exploration activities by the beneficiaries of its munificence. Lastly, such an allowance has been recommended to the Department in Ottawa upon at least three previous occasions, but the Department has hitherto maintained a stony silence.

It is the writer's opinion that a depletion allowance of $25 \%$, based upon gross income, should be introduced in Canada, qualified by a limitation that it must not exceed, let us say $75 \%$ of the taxpayer's gross expenditures upon exploration. In this way, a much more reasonable and adequate depletion allowance, on a current basis, would be granted to the taxpayer than he can hope for under the present allowance. At the same time, the taxpayer would be provided with an incentive to explore, because the more he spent upon exploration, the less restrictive would be the limitation upon his allowable depletion. Furthermore, a gross allowance with a limitation should be much more palatable to the fiscus in Ottawa, since 
it would not precipitate anything like the drastic reduction in taxes paid in Canada that would result from the completely unlimited gross depletion allowances proposed by the Canadian Petroleum Association and the Independent Petroleum Association of Canada.

Alternatively, for those petroleum companies which do not or cannot engage in further exploration activities in Canada, but which do own producing properties, it is submitted that some recognition of the physical depletion of their interests is still justified. Therefore, if such companies were allowed to continue claiming depletion on the present $331 / 3 \%$ of net income basis, they would not be prejudiced by the aforementioned limitation upon depletion which would vary according to their expenditures upon exploration. An option should be granted to all taxpayers permitting them to claim the greater of the current depletion allowance or the limited gross allowance which has been recommended.

It is perhaps worthy of comment here that some petroleum companies which are in a taxable position in Canada, have found it worth while to separate their expensive exploration activities from their production activities in two separate corporate entities. In this manner, large expenditures upon the acquisition of new properties and upon the drilling of costly wildcat wells are prevented from diminishing the profits from the sale of production which are subject to depletion. Such corporate maneuvering, while ingenious in concept and sound in law and ethics, is feasible in only very limited circumstances. In addition it is mute but eloquent testimony to the fact that our depletion allowance has gone astray from its objectives to a serious degree.

The writer expects no accolades for these expressions of opinion from any taxpayer who has pined his hopes upon Parliament granting the unlimited 25\% gross depletion allowance as proposed to the Royal Commission on Taxation. However, even though a prophet has no honor in his own land, if the more conservative proposals which have been ventured here should find acceptance, it is submitted the Canadian petroleum industry would be able to compete upon reasonably equal terms with its competitors for the first time in its life.

In conclusion, the writer wishes to leave a word of hope for those who are by now depressed by this long recital of calamitous visitations upon the petroleum industry in Canada through the machinations of our tax laws. A sage observed some time ago that this is indeed a land of opportunity, for where else can you borrow maney at an interest rate of $6 \%$ to pay your taxes? 